\title{
Penile Mondor's Disease: Case Report and Literature Review
}

\author{
Nabil Jakhlal ${ }^{1,2 *}$, Alae Touzani ${ }^{1,2}$,Abdelouahed Lasri ${ }^{1,2}$, Tariq Karmouni ${ }^{1,2}$, Khalid El Khader ${ }^{1,2}$, Abdellatif \\ Koutani ${ }^{1,2}$ and Ahmed IbnAttya Andaloussi ${ }^{1,2}$ \\ ${ }^{1}$ Department of Medicine and Pharmacy, Mohammed V University, Morocco \\ ${ }^{2}$ Department of Urology, Ibn Sina Teaching Hospital, Morocco
}

Submission: September 8, 2017; Published: November 16, 2017

*Corresponding author: Nabil Jakhlal, Department of Medicine and Pharmacy, Mohammed V University, Morocco, Tel: +212 615327218 ; Email: doc.nabil54@gmail.com

\begin{abstract}
Penile Mondor's disease is a thrombophlebitis of the superficial dorsal vein of the penis. We report here the case of a 37 year-old male, who consulted for a painful and indurated cord on the dorsal side of the penis. The patient underwent vein removal after failure of spontaneous
\end{abstract} resolution.

Keywords: Mondor's disease; Penis; Superficial venous thrombosis

\section{Case Report}

We report here the case of 37 years-old unmarried male, with no medical history, who consulted for a redness and edema of the penis after a sexual intercourse, 3 years ago. The evolution is marked by the persistence of a sclerotic cord on the dorsal side of the penis, painful during erection (Figure 1). We diagnosis a chronic-stage penile Mondor's disease, and we performed a superficial vein stripping (Figure 2\&3). The histological study shows a focal intimal thickening of the venous wall without obstruction of vascular light, and an absence of thrombus.

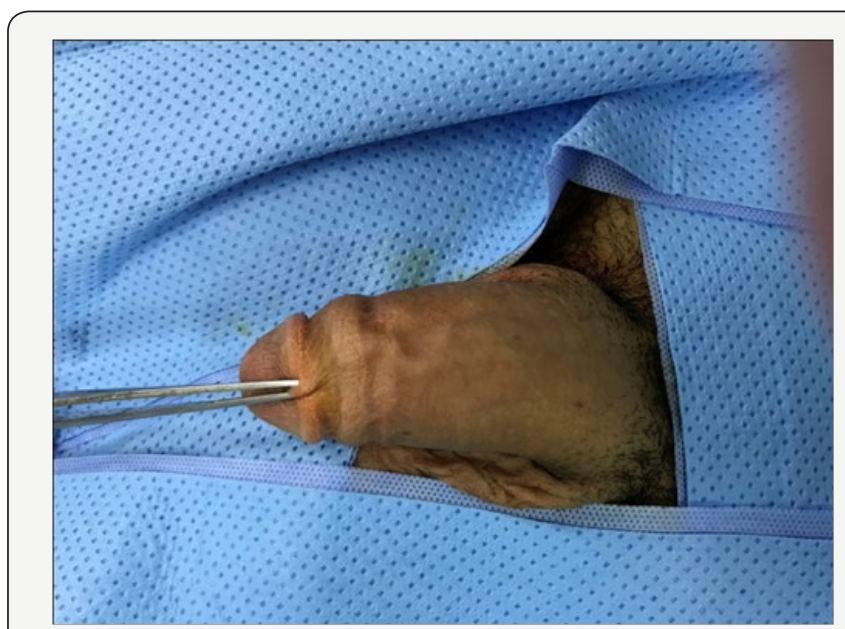

Figure 1: Inflammatory cord at the dorsal side of the penis.

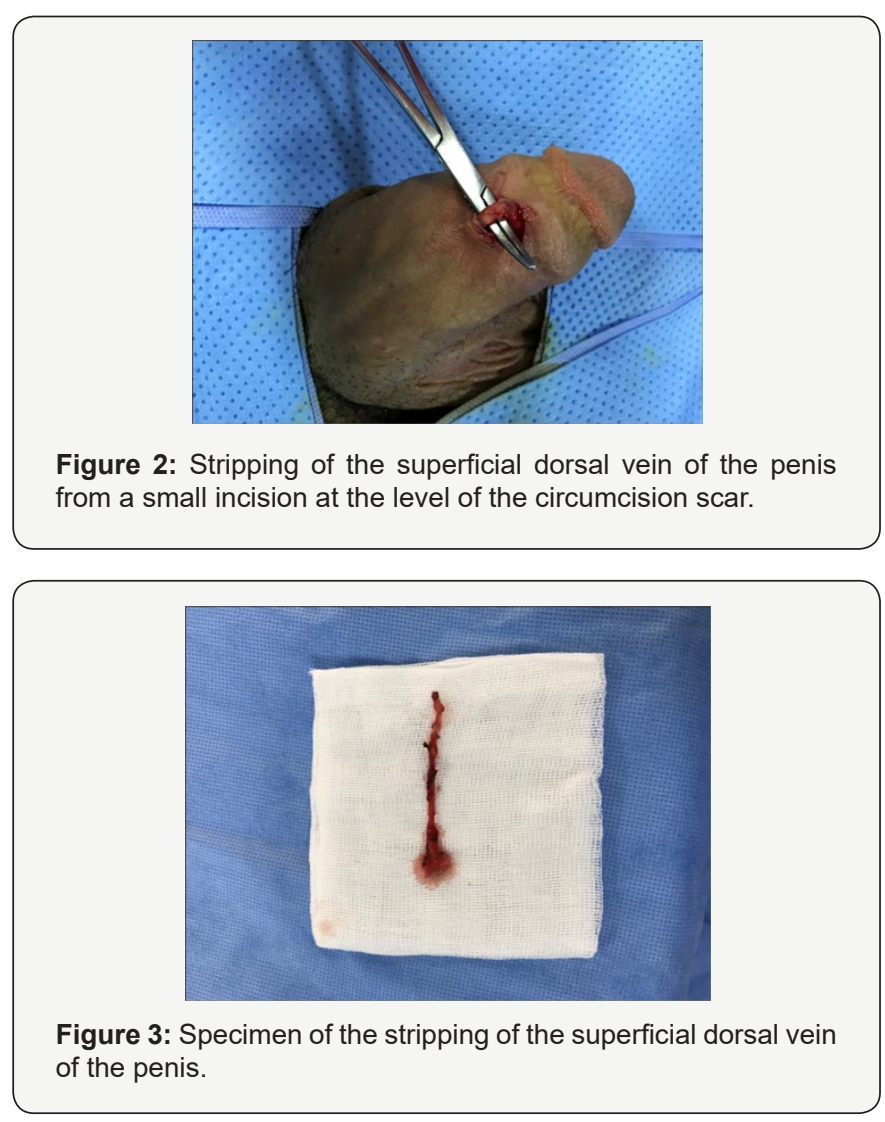




\section{Global Journal of Reproductive Medicine}

\section{Discussion}

Superficial vein thrombosis was initially described by Mondor [1] in 1939 in the subcutaneous veins of the anterolateral thoraco-abdominal wall [1]. Penile Mondor's disease was described for the first time in 1955 by Braun-Falco [2], then by Helm \& Hodge [3] in 1958. It's a rare and poorly known benign genital disease. There are about sixty clinical cases published in the literature nowadays $[4,5]$. It occurs in sexually active men, most often between 21 and 70 years [6]. Physiopathologically, it is important to differentiate between the two penile venous networks. Mondor's disease touches the superficial, subcutaneous network. This superficial network begins at the base of the glans and then drains the envelopes of the penis in complex arborescence which goes for some, towards the scrotum and merges with the veins of this region and for the others, towards the upper side of the penis forming the superficial dorsal vein. A thrombophlebitis of this network is rather benign.

The deep network is constituted by the deep dorsal vein which is born from the balanic veins surrounding the glans, joined by the circumflex veins draining the spongy body and the corpora cavernosa. Thrombophlebitis of the deep network is a surgical emergency. Etiopathogenesis remains unknown, but many predisposing factors have been highlighted in the literature: prolonged sexual intercourse, traumatic intercourse, prolonged sexual abstinence, local infectious processes (syphilis, candidiasis), injection of intracavalous products, vacuum use, local surgery (cure of an inguinal hernia, vasectomy, orchidopexy) or oncological causes (pelvic cancer, para-neoplasia) $[7,8]$. The diagnosis of dorsal superficial venous thrombosis of the penis is clinical and based on anamnesis and physical examination. It often shows an indurated cord on the dorsal side of the penis, which corresponds to the thrombosed dorsal vein, which has become thick and adherent to the underlying skin. Often, the lesion will extend cranially into suprapubic area, and the vein may appear swollen and erythematous. A penile echo-doppler can be performed especially in cases of diagnostic doubt. It can also be performed to confirm diagnosis and monitor the disease in case of conservative treatment. It usually shows a venous thrombus in the superficial vein of the penis and/or absence of venous flow $[4,5]$.

The differential diagnosis is mainly sclerosinglymphangitis. The main features of this disease are: intense sexual activity preceding 24- to 48-hour the apparition of lesions, localization of a characteristic serpiginous cord at the circumcision scar, normal biological examination, and spontaneous rapid resolution with or without us of nonsteroidal anti-inflammatory drugs [9]. Thus, the presence of a thrombus of the superficial vein of the penis and / or an absence of the venous flow on the echo-doppler allows establishing the diagnosis of the penile Mondor's disease [4]. Treatment of thrombosis of the superficial vein of the penis can range from simple monitoring to surgical treatment. In studies where patients had not received any treatment, healing was obtained after 6 to 8 weeks with re-permeabilization of the thrombosed vein [7]. In a study of 14 patients, Mürsel DEO [10] found that oral administration of acetyl salicyllic acid (2g per day) combined with Pentoxifylline (1200mg per day) would reduce the duration of symptoms. However, it was found that this time corresponded to that of the spontaneous resolution of the symptoms [11]. The administration of platelet anti aggregants does not accelerate healing and is not necessary for the prevention of additional thrombosis. Currently, the treatment is symptomatic in several patients. However, antibiotic therapy may be associated with cellulitis or exposure to sexually transmitted diseases. Stripping or thrombectomy can be proposed in the chronic forms of penile Mondor's disease or in resistant forms to treatment (persistence of the symptomatology and absence of permeabilization of the vein at 6 weeks) [8].The main recommendation for treatment is sexual abstinence until remission of symptoms.

\section{Conclusion}

Penile Mondor's disease is rare, easy to diagnosis and its evolution is most often favorable. Its treatment is based on sexual abstinence, the use of non-steroidal anti-inflammatory drugs, and the superficial vein stripping or thrombectomy in advanced cases. This pathology deserves to be known in order to distinguish it from sclerosinglymphangitis and other penile pathologies, to reassure the patient on the functional outcome and to know when to propose a surgical treatment.

\section{References}

1. Mondor H (1939) Tonculite sous-cutanéesubaiguë de la paroithoraciqueantérolatérale. Mem AcadChir 65: 1258-1271.

2. Braun Falco 0 ZurKlinik (1955) histologie, undpathogenese der strang formigenoberflachlichen phlebitiden. Dermatol Wochenschr 132: 705715

3. Helm JD, Hodge IG (1958) Thrombophlebitis of a dorsal vein of penis, report of a case treated by phenylbutazone. J Urol 79(2): 306-307.

4. Öztürk H(2014) Penile Mondor's disease. Basic and Clin Androl 24: 5.

5. Marsaudon E, Legal C, Gayoux D, Weber O (2016) La maladie de Mondor pénienne: une observationMondor's disease of penis: A case report 37(9): 636-3638.

6. Nazir SS, Khan M (2010) Thrombosis of the dorsal vein of the penis (Mondor's Disease): A case report and review of the literature. Indian J Urol 26(3): 431-433.

7. Nachmann MM, Jaffe JS, Ginsberg PC, Horrow MM, Harkaway RC (2003) Sickle cell episode manifesting as superficial thrombo phlebitis of the penis. JAOA 103(2): 102-104.

8. Sasso F, Gulino G, Basar M, Carbone A, Torricelli P, et al. (1996) Penile Mondor's disease: an under estimated pathology. Br J Urol 77:729-732.

9. Jmour Y, Litaiem N (2016) Lymphangite sclérosante de la verge. Annales de Dermatologie et de Vénérologie 143(4): S19-S20.

10. Mürsel DEO (2010) Penile Mondor's disease can be effectively treated with the use of an acetyl salicylic acid and pentoxifylline combination. Turk J Med Sci 40(5):735.

11. Walsh JC, Poimboeuf S, Garvin DS (2014) A common presentation to an uncommon disease. Penile Mondor's disease: a case report and literature review. Int Med Case Rep J 7: 155-157. 
DOI:_10.19080/GJORM.2017.02.555599
Your next submission with Juniper Publishers will reach you the below assets

- Quality Editorial service

- Swift Peer Review

- Reprints availability

- E-prints Service

- Manuscript Podcast for convenient understanding

- Global attainment for your research

- Manuscript accessibility in different formats

( Pdf, E-pub, Full Text, Audio)

- Unceasing customer service

Track the below URL for one-step submission https://juniperpublishers.com/online-submission.php 